\title{
Single nucleotide polymorphisms at the imprinted bovine insulin-like growth factor 2 (IGF2) locus are associated with dairy performance in Irish Holstein-Friesian cattle
}

\author{
Erik W Berkowicz ${ }^{1}$, David A Magee ${ }^{1}$, Klaudia M Sikora ${ }^{2}$, Donagh P Berry ${ }^{3}$, Dawn J Howard ${ }^{4}$, \\ Michael P Mullen ${ }^{4}$, Ross D Evans ${ }^{5}$, Charles Spillane ${ }^{2}$ and David E MacHugh ${ }^{1,6}$ \\ ${ }^{1}$ Animal Genomics Laboratory, UCD School of Agriculture, Food Science and Veterinary Medicine, University College Dublin, \\ Belfield, Dublin 4, Ireland \\ ${ }^{2}$ Genetics and Biotechnology Laboratory, Department of Biochemistry, University College Cork, Cork, Ireland; Current address: \\ Genetics and Biotechnology Laboratory, Centre for Chromosome Biology, National University of Ireland Galway, Ireland \\ ${ }^{3}$ Moorepark Dairy Production Research Centre, Teagasc, Fermoy, Co. Cork, Ireland \\ ${ }^{4}$ Animal Production Research Centre, Teagasc, Mellows Campus, Athenry, Co. Galway, Ireland \\ ${ }^{5}$ Irish Cattle Breeding Federation, Highfield House, Bandon, Co. Cork, Ireland \\ ${ }^{6}$ UCD Conway Institute of Biomolecular and Biomedical Research, University College Dublin, Dublin 4, Ireland
}

Received 29 April 2010; accepted for publication 9 July 2010; first published online 8 September 2010

\begin{abstract}
The imprinted insulin-like growth factor 2 gene (IGF2) encodes a fetal mitogenic hormone protein (IGF-II) and has previously been shown to be associated with performance in dairy cattle. In this study we assessed genotype-phenotype associations between four single nucleotide polymorphisms (SNPs) located within the bovine IGF2 locus on chromosome 29 and a range of performance traits related to milk production, animal growth and body size, fertility and progeny survival in 848 progeny-tested Irish Holstein-Friesian sires. Two of the four SNPs (rs42196909 and IGF2.g-3815A $>G)$, which were in strong linkage disequilibrium $\left(r^{2}=0.995\right)$, were associated with milk yield $(P \leqslant 0 \cdot 01)$ and milk protein yield $(P \leqslant 0 \cdot 05)$; the $r s 42196901$ SNP was also associated $(P \leqslant 0 \cdot 05)$ with milk fat yield. Associations $(P \leqslant 0 \cdot 05)$ with milk fat percentage and milk protein percentage were observed at the rs42196901 and IGF2.g-3815A>G SNPs, respectively. The rs42196909 and IGF2.g-3815A>G SNPs were also associated with progeny carcass conformation $(P \leqslant 0 \cdot 05)$, while an association $(P \leqslant 0 \cdot 01)$ with progeny carcass weight was observed at the $r 42194733$ SNP locus. None of the four SNPs were associated with body size, fertility and progeny survival. These findings support previous work which suggests that the IGF2 locus is an important biological regulator of milk production in dairy cattle and add to an accumulating body of research showing that imprinted genes influence many complex performance traits in cattle.
\end{abstract}

Keywords: Bos, cattle, genetic imprinting, IGF2, performance traits, single nucleotide polymorphism.

Genetic studies have shown that the paternally inherited and maternally inherited genomes in eutherian mammals are not functionally equivalent. This is most aptly illustrated by genetic (or 'genomic') imprinting, a form of epigenetic regulation that results in the preferential expression of an allele from one of the two parentally inherited chromosomes in a parent-of-origin manner (McGrath \& Solter, 1984; Surani et al. 1984). To date, nearly 100 imprinted mammalian genes have been identified, many of which play important roles in fetal growth and development (Bartolomei, 2009; Feil, 2009).

*For correspondence; e-mail : david.magee@ucd.ie
The insulin-like growth factor 2 gene (IGF2), which encodes a fetal mitogenic protein (IGF-II) structurally related to insulin (O'Dell \& Day, 1998), has been the most extensively studied imprinted mammalian gene owing to its pivotal role in the regulation of embryonic development and relationship to disease (Reik et al. 2000; Rodriguez et al. 2007). In mammals, IGF2 is expressed preferentially from the paternally inherited allele in most embryonic tissues and forms a conserved imprinted gene cluster with the reciprocally imprinted, non-protein coding H19 gene, which is highly expressed in embryonic and fetal tissue but whose function remains unclear (Bartolomei et al. 1991; Rachmilewitz et al. 1992; Giannoukakis et al. 1993; 
Feil et al. 1998; McLaren \& Montgomery, 1999; Dindot et al. 2004a; Dindot et al. 2004b; Zhang et al. 2004; Li et al. 2008). The detection of biallelic IGF2 expression in certain mammalian post-natal and adult tissues, however, does suggest that monoallelic expression of this gene is both tissue- and developmental-stage specific (Dindot et al. 2004b; Curchoe et al. 2005; Goodall \& Schmutz, 2007; Chao \& D'Amore, 2008; Li et al. 2008).

The majority of studies involving IGF2 have focused on mouse models and human biomedical disorders (Chao \& D'Amore, 2008); however, there is growing interest in the role of IGF2 in domestic livestock. For example, DNA sequence polymorphisms within IGF2 have been shown to contribute to variation in complex production traits, notably muscle mass and fat deposition in pigs (Jeon et al. 1999; Nezer et al. 1999; Nezer et al. 2002; Van Laere et al. 2003). Since these early studies, a range of SNPs distributed across the porcine IGF2 gene have been shown to be associated with carcass traits, meat production, body size, fertility and survival traits in pigs (Vykoukalova et al. 2006; Stinckens et al. 2007; Heuven et al. 2009; Oczkowicz et al. 2009; Hou et al. 2010; Stinckens et al. 2010).

According to the Ensembl database (http://www. ensembl.org), the current fully annotated bovine IGF2 gene is located at the telomeric end of chromosome 29 (BTA29) and consists of five exons, the first two of which are untranslated (Ensembl gene ID ENSBTAG00000013066; Ensembl transcript ID ENSBTAT00000017372). Two alternative RNA transcripts have also been reported from this gene (Ensembl transcript IDs ENSBTAT00000044139 and ENSBTAT00000044140). Recently, there have been a number of publications detailing associations between DNA sequence polymorphisms in the bovine IGF2 gene and meat and milk production traits in beef and dairy cattle, respectively (Flisikowski et al. 2007; Goodall \& Schmutz, 2007; Sherman et al. 2008; Bagnicka et al. 2010), hence we hypothesized that DNA sequence polymorphisms within this gene may also be associated with performance traits within a population of progeny-tested Irish Holstein-Friesian artificial insemination (AI) sires.

Previously, we validated 15 SNPs in the bovine IGF2 gene (Magee et al. 2010). In the present study, we investigated genotype-phenotype associations between four of these SNPs distributed across a $\sim 31$ kilobase $(\mathrm{kb})$ region of Bos taurus chromosome 29 (BTA29) encompassing the bovine IGF2 gene and genetic merit for a range of performance traits in 848 Irish Holstein-Friesian Al sires, estimated from progeny performance.

\section{Materials and Methods}

\section{SNP validation}

The methods used to validate DNA sequence polymorphisms within, or proximal to, the bovine IGF2 gene have been discussed in detail elsewhere (Magee et al. 2010).
Briefly, high-fidelity polymerase chain reaction (PCR) amplicons spanning putative IGF2-associated SNPs on BTA29 (as per build BTAU_4.0 of the bovine genome in the Ensembl database: http://www.ensembl.org) were generated for a panel of 26 animals of wide geographic provenance and sequenced bi-directionally (Macrogen Inc., Seoul, Korea). The MEGA 4.0 software package (Tamura et al. 2007) was used to analyse all resulting DNA sequences, validate the SNPs reported in Ensembl and identify novel SNPs in the re-sequenced regions.

In the current study, four validated SNPs distributed across a 30827 base pair (bp) region spanning the bovine IGF2 gene (Ensembl gene ID ENSBTAG00000013066) were selected for high-throughput genotyping: rs42196909, IGF2.g-3815A>G, rs42194733 and rs42196901 (Table 1). These SNPs were selected as they are distributed across the full length of the annotated bovine IGF2 gene and displayed minor allele frequencies (MAF) $\geqslant 0.18$ in a panel of 138 European B. taurus animals screened previously by us (Magee et al. 2010). Based on the current annotation of the bovine IGF2 gene in the Ensembl database, two SNPs were located upstream of the IGF2 gene (rs42196909 and IGF2.g-3815A>G), one SNP (rs42194733) was located in an intron between the 2 nd and 3 rd exon of the IGF2 gene, and one SNP (rs42196901) was located downstream of the IGF2 gene. All SNPs represented transitions.

It is important to note that the IGF2.g-3815A $>G$ is not currently deposited within the dbSNP database (http:// www.ncbi.nih.gov/projects/SNP); however, this SNP has previously been reported by us (Magee et al. 2010), where it was listed as SNP IGF2_08. In the current study we have recoded this SNP using the guidelines of the Human Genome Variation Society (http://www.hgvs.org). This SNP was named by first listing the nearest gene (i.e. IGF2) followed by '. $g$ ' to denote genomic DNA, '-3815' to denote the position of this SNP relative to the transcriptional start site (i.e. $3815 \mathrm{bp}$ upstream of the IGF2 gene based on Ensembl transcript ID ENSBTAT00000017372) and finally ' $A>G$ ' to denote the alleles present at this locus.

\section{DNA samples, DNA extraction, high-throughput SNP genotyping and SNP data filtering}

Genomic DNA from 914 Irish Holstein-Friesian Al bulls was purified using a Maxwell ${ }^{\mathrm{TM}} 16$ automated apparatus (Promega Corp., Madison WI, USA) according to the manufacturer's instructions. These bulls have been used to produce progeny in Ireland and are representative of the commercial germplasm used in Irish dairy herds in recent years. All four IGF2 SNPs were genotyped in all 914 sires (together with an additional 25 independently extracted, duplicate samples that were included for genotype quality control purposes) using the MassARRAY ${ }^{\circledR}$ iPLEX $^{\mathrm{TM}}$ Gold genotyping platform provided by Sequenom Inc. (San Diego CA, USA; http//:www.sequenom.com). This SNP genotyping method discriminates between SNP alleles using 
Table 1 Summary statistics for the IGF2-associated SNPs analysed across 848 Holstein-Friesian sires analysed in this study†

\begin{tabular}{|c|c|c|c|c|c|c|}
\hline SNP ID & $\begin{array}{l}\text { Location of } \\
\text { SNP relative } \\
\text { to the bovine } \\
\text { IGF2 gene }\end{array}$ & $\begin{array}{l}\text { SNP location } \\
\text { on BTA29 }\end{array}$ & Genotypes & $\begin{array}{l}\text { Genotype } \\
\text { frequencies }\end{array}$ & $\begin{array}{l}\text { Minor } \\
\text { allele } \\
\text { frequency }\end{array}$ & $\begin{array}{l}\text { Deviations } \\
\text { from HWE } \\
(P \text { value })\end{array}$ \\
\hline rs42196909 & Upstream & 51250879 & $\begin{array}{l}\text { GG } \\
\text { AG } \\
\text { AA }\end{array}$ & $\begin{array}{l}0 \cdot 40 \\
0 \cdot 45 \\
0 \cdot 15\end{array}$ & $0 \cdot 38(\mathrm{~A})$ & $0 \cdot 28$ \\
\hline IGF2.g-3815A>G & Upstream & 51254122 & $\begin{array}{l}\text { GG } \\
\text { AG } \\
\text { AA }\end{array}$ & $\begin{array}{l}0 \cdot 40 \\
0 \cdot 45 \\
0 \cdot 15\end{array}$ & $0 \cdot 38(\mathrm{~A})$ & $0 \cdot 28$ \\
\hline rs42194733§ & Intronic & 51263683 & $\begin{array}{l}\text { CC } \\
\text { CT } \\
\text { TT }\end{array}$ & $\begin{array}{l}0 \cdot 55 \\
0 \cdot 37 \\
0 \cdot 08\end{array}$ & $0 \cdot 26(\mathrm{~T})$ & 0.06 \\
\hline rs42196901§ & Downstream & 51281706 & $\begin{array}{l}\text { AA } \\
\text { GA } \\
\text { GG }\end{array}$ & $\begin{array}{l}0 \cdot 79 \\
0 \cdot 19 \\
0 \cdot 02\end{array}$ & $0 \cdot 12(\mathrm{G})$ & 0.02 \\
\hline
\end{tabular}

+ Genotype and allele frequencies, and the significance of deviations from Hardy-Weinberg equilibrium (HWE) based on $P$-values obtained from $\chi^{2}$-test results are shown for all four IGF2-associated SNPs. All SNP nucleotide positions (on BTA29) were obtained from the Build 4.0 of the B. taurus genome sequence on the Ensembl database (http://www.ensembl.org, release 58, as per Ensembl gene ID ENSBTAG00000013066) or the UCSC genome browser (http://genome.ucsc.edu). All SNPs genotyped are located on BTA29. The open reading frame (ORF) gene model positions for each SNP are given \# Details of the SNP nomenclature used is given in the Materials and Methods section of the manuscript $\S$ The dbSNP accession for the analysed SNP

single base primer extension technology after which primer extension products are analysed using matrixassisted laser desorption ionization time-of-flight (MALDITOF) mass spectroscopy (http://www.sequenom.com/iplex). Following quality control on all genotype data (Waters et al. 2010) genotypes for 848 bulls remained. The SNP genotype concordance rate between technical replicate for these SNPs was $100 \%$.

A range of phenotypic traits were analysed in this study and were categorized into seven broad categories: (1) milk production traits (milk yield, fat yield, protein yield, milk fat and protein percentage); (2) udder health (somatic cell count, SCC); (3) carcass traits (cow carcass weight, progeny carcass weight, subcutaneous carcass fat level and carcass conformation score); (4) growth and size related traits in live animals (stature, chest width, body depth, rump width); (5) subjectively assessed subcutaneous fat level on live animals (angularity and body condition score); (6) calving traits (direct calving difficulty, maternal calving difficulty, perinatal mortality); and (7) fertility and survival (calving interval and functional survival). Sire predicted transmitting ability (PTA) was the dependent variable for all traits with the exception of the milk production traits, including SCC, which were daughter yield deviations (DYDs) expressed on a PTA scale.

Models used in genetic evaluations in Ireland, as well as variance components, have been previously described in detail by Berry et al. (2009) and summarized by Waters et al. (2010). All PTAs were de-regressed using the procedure outlined by Berry et al. (2009). Only sires with a reliability score, less parental contribution, of $>60 \%$ were retained for inclusion in the association analysis. A total of 742 sires fulfilled this criterion for inclusion in the analysis of milk, fat and protein yield as well as milk fat and protein concentration and the number of sires included for calving interval and survival was 501 and 477, respectively. The numbers of sires for direct calving difficulty, maternal calving difficulty, and perinatal mortality were 575, 506 and 201, respectively. The number of sires with a reliability of $>60 \%$ for the carcass traits was 446 and the number of sires with a reliability of $>60 \%$ for the size linear type traits varied from 484 to 551 .

The association between each SNP and performance was quantified using weighted mixed linear models in ASReml (Gilmour et al. 2009), with individual included as a random effect, and average expected relationships among individuals accounted for through the numerator relationship matrix. Year of birth (divided into five-yearly intervals) and percent Holstein of the individual sire were included as fixed effects in the model. In all instances the dependent variable was de-regressed PTA or DYD, weighted by their respective reliability, less the parental contribution. Genotype was included in the analysis as a continuous variable coded as the number of copies of a given allele. The Haploview package (Barrett et al. 2005) was used to measure $r^{2}$ and $D^{\prime}$ values of linkage disequilibrium (LD) between pair-wise combinations of segregating SNPs (Lewontin, 1964; Hill \& Robertson, 1968).

\section{Results and Discussion}

Summary statistics for the four analysed IGF2 locus SNPS

Summary statistics, including genotype and allele frequencies together with deviations from Hardy-Weinberg equilibrium (HWE), for each of the four genotyped IGF2 


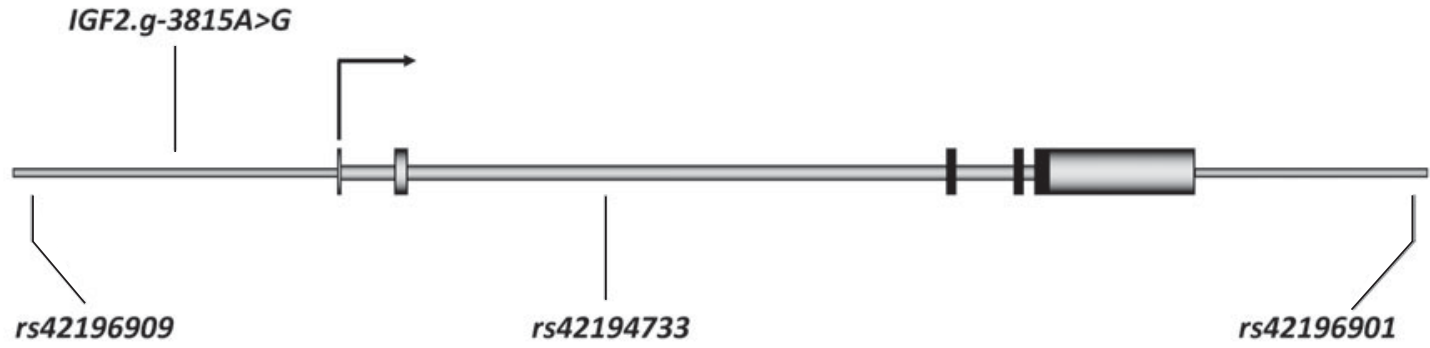

\section{Gene symbols}

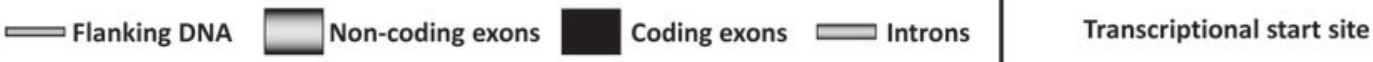

Fig. 1. Location of the four bovine IGF2-associated SNPs analysed in this study based on ORF model for the annotated IGF2 gene transcript (Ensembl transcript ID ENSBTAT00000017372; BTA29) as per Ensembl release 58 of the B. taurus genome.

SNPs are presented in Table 1 and the location of all four SNPs is depicted graphically in Fig. 1. Minor allele frequencies (MAF) for all analysed loci were $\geqslant 0 \cdot 12$. Observed heterozygosity (i.e. the proportion of heterozygous individuals within the analysed sire population) ranged from 0.19 (rs42196901) to 0.45 (rs42196909 and IGF2.g-3815A $>G$ ) with a mean observed heterozygosity of 0.37 across all four loci. Only one SNP (rs42196901) exhibited a significant deviation from HWE $(P=0 \cdot 02)$. This was due to an observed excess of homozygous individuals for the ' $\mathrm{C}$ ' allele (observed proportion of $\mathrm{C} / \mathrm{C}$ individuals $=0.021$; expected proportion $=0.013$ ) and may be explained by random sampling.

Inspection of the $r^{2}$ values of LD for all pairwise SNP combinations (Table 2) demonstrated that the rs42196909 and IGF2.g-3815A>G SNPs, which are separated by a total of $3243 \mathrm{bp}$, were in strong LD $\left(r^{2}=0.995\right)$, suggesting that they represent an IGF2 haplotype. This is further supported by the identical allele and genotype frequencies observed at these markers (Table 1). All remaining pairwise SNP combinations displayed $r^{2}$ values $\leqslant 0 \cdot 230$ suggesting the existence of discrete haplotype blocks within the $30 \cdot 8 \mathrm{~kb}$ genomic region analysed. LD statistics for each pairwise SNP combination are presented in Table 2.

\section{Associations with carcass and body conformation traits}

Significant phenotype-genotype associations for all SNPs analysed are detailed in Table 3. In the current study, one of the four bovine SNPs (rs42194733) within the bovine IGF2 locus was significantly associated $(P<0 \cdot 01)$ with progeny carcass weight: a T-to-C allele substitution at this intronic SNP was associated with gain in progeny carcass weight. The rs42194733 was not associated with any of
Table 2. Pairwise SNP linkage disequilibrium (LD) statistics for the four IGF2-associated SNPs analysed in this study

\begin{tabular}{|c|c|c|c|c|}
\hline SNP 1 & SNP 1 & $\begin{array}{l}\text { Distance } \\
\text { between } \\
\text { SNPs } \\
\text { in bp }\end{array}$ & $r^{2}$ & $\mathrm{D}^{\prime}$ \\
\hline rs42196909 & $I G F 2 . g-3815 A>G$ & 3243 & 0.995 & $1 \cdot 000$ \\
\hline rs42196909 & rs42194733 & 12804 & $0 \cdot 229$ & $1 \cdot 000$ \\
\hline rs42196909 & rs42196901 & 30827 & $0 \cdot 115$ & 0.719 \\
\hline$I G F 2 . g-3815 A>G$ & rs42194733 & 9561 & $0 \cdot 230$ & $1 \cdot 000$ \\
\hline$I G F 2 . g-3815 A>G$ & rs42196901 & 27584 & $0 \cdot 116$ & 0.731 \\
\hline$r s 42194733$ & rs42196901 & 18023 & $0 \cdot 027$ & 0.737 \\
\hline
\end{tabular}

the other performance traits analysed in this study. In addition, the two SNPs located upstream of the bovine IGF2 gene (rs42196909 and IGF2.g-3815A>G), both of which were in strong LD, were associated $(P \leqslant 0.05)$ with overall carcass conformation-a visually assessed measure of animal muscularity (Butterfield, 1988). Both the G-to-A substitutions at the rs42196909 and IGF2.g-3815A>G loci were associated $(P \leqslant 0 \cdot 05)$ with small increases in progeny carcass conformation, which are indicative of increased muscle mass. With the exception of these associations, none of the four assayed SNPs were associated with any of the other carcass, body conformation and body size traits analysed (listed in the Materials and Methods section). Also, although a recent study reported associations between SNPs within the porcine IGF2 gene and prolificacy and longevity in pigs (Stinckens et al. 2010), no associations with fertility or survival were observed here.

These observations suggest that the bovine IGF2 locus may harbour a QTL for muscle mass in cattle, an assertion which is supported by previous animal genetic studies. 
Table 3 Significant allele substitution effects between the four IGF2 SNPs and milk traits and carcass traits. SE for each trait is shown in parentheses.

\begin{tabular}{|c|c|c|c|c|c|c|c|c|}
\hline SNP & $\begin{array}{l}\text { Allele } \\
\text { substitution }\end{array}$ & $\begin{array}{l}\text { Milk yield, } \\
\text { kg/lactation }\end{array}$ & $\begin{array}{l}\text { Milk protein } \\
\text { yield, } \\
\text { kg/lactation }\end{array}$ & $\begin{array}{l}\text { Milk fat } \\
\text { yield, } \\
\text { kg/lactation }\end{array}$ & $\begin{array}{l}\text { Milk fat } \\
\text { percentage } \neq \\
(\times 10)\end{array}$ & $\begin{array}{l}\text { Milk protein } \\
\text { percentage } \neq \\
(\times 10)\end{array}$ & $\begin{array}{l}\text { Carcass } \\
\text { weight }(\mathrm{kg})\end{array}$ & $\begin{array}{l}\text { Carcass } \\
\text { conformation§ } \\
\text { [scale } 1 \text { (low) } \\
\text { to } 15 \text { (high)] }\end{array}$ \\
\hline rs42196909 & $A \rightarrow G$ & $\begin{array}{c}28 \cdot 40^{* *} \\
(9 \cdot 89)\end{array}$ & $\begin{array}{c}0 \cdot 63^{*} \\
(0 \cdot 27)\end{array}$ & $\begin{array}{c}0 \cdot 42 \\
(0 \cdot 35)\end{array}$ & $\begin{array}{c}-0 \cdot 13 t \\
(0 \cdot 08)\end{array}$ & $\begin{array}{c}-0.07+ \\
(0.04)\end{array}$ & $\begin{array}{r}-0 \cdot 37 \\
(0 \cdot 49)\end{array}$ & $\begin{array}{r}-0.04^{*} \\
(0.02)\end{array}$ \\
\hline$I G F 2 . g-3815 A>G$ & $A \rightarrow G$ & $\begin{array}{c}30 \cdot 31^{* *} \\
(9 \cdot 78)\end{array}$ & $\begin{array}{c}0 \cdot 66^{*} \\
(0 \cdot 27)\end{array}$ & $\begin{array}{c}0 \cdot 51 \\
(0 \cdot 35)\end{array}$ & $\begin{array}{c}-0 \cdot 12 \dagger \\
(0 \cdot 07)\end{array}$ & $\begin{array}{c}-0.07^{*} \\
(0.04)\end{array}$ & $\begin{array}{r}-0 \cdot 45 \\
(0 \cdot 48)\end{array}$ & $\begin{array}{r}-0.04^{*} \\
(0.02)\end{array}$ \\
\hline rs42194733 & $\mathrm{C} \rightarrow \mathrm{T}$ & $\begin{array}{c}11 \cdot 59 \\
(10 \cdot 39)\end{array}$ & $\begin{array}{c}0 \cdot 31 \\
(0 \cdot 29)\end{array}$ & $\begin{array}{c}0 \cdot 25 \\
(0 \cdot 37)\end{array}$ & $\begin{array}{r}-0.06 \\
(0 \cdot 08)\end{array}$ & $\begin{array}{r}-0 \cdot 02 \\
(0 \cdot 04)\end{array}$ & $\begin{array}{c}-1 \cdot 39^{* *} \\
(0 \cdot 52)\end{array}$ & $\begin{array}{r}-0.03 \\
(0 \cdot 02)\end{array}$ \\
\hline rs42196901 & $\mathrm{G} \rightarrow \mathrm{A}$ & $\begin{array}{c}1.91 \\
(14 \cdot 29)\end{array}$ & $\begin{array}{c}-0 \cdot 45 \\
(0 \cdot 40)\end{array}$ & $\begin{array}{c}-1 \cdot 03^{*} \\
(0 \cdot 50)\end{array}$ & $\begin{array}{c}-0 \cdot 21^{*} \\
(0 \cdot 11)\end{array}$ & $\begin{array}{l}0.09+ \\
0.05\end{array}$ & $\begin{array}{c}0 \cdot 76 \\
(0 \cdot 68)\end{array}$ & $\begin{array}{c}0.04 \\
(0 \cdot 03)\end{array}$ \\
\hline
\end{tabular}

₹A value of 1 prior to multiplication by 1000 equates to 1 percentage unit §See Materials and Methods for details

Significance of difference from zero: $+P \leqslant 0 \cdot 10 ;{ }^{*} P \leqslant 0 \cdot 05 ; * * P \leqslant 0 \cdot 01$

QTL mapping studies in cattle initially identified BTA29the chromosome to which the bovine IGF2 locus mapsas containing a QTL influencing muscle mass in cattle (Casas et al. 2003). More recently, genetic studies have revealed association between a single IGF2 C-to-T SNP [designated IGF2c.-292C>T (Goodall \& Schmutz, 2003)] and meat traits (including rib eye area and body fat content) and body weight in beef cattle (Goodall \& Schmutz, 2007; Sherman et al. 2008). Also, Schmutz \& Goodall (2005) reported that the C allele of this SNP was associated with lighter birth weight, while Sherman et al. (2008) have reported that Aberdeen Angus animals with the TT genotype for this marker displayed increased average daily weight gain.

Studies in pigs have also shown that DNA sequence variation in the porcine IGF2 gene directly contributes to growth and carcass traits. Notably, a single G-to-A substitution within a regulatory region of the $3 \mathrm{rd}$ intron of the IGF2 gene (termed 'IGF2 intron3 g.3072G $>A$ ') which is directly responsible for a QTL influencing muscle mass and fat deposition in pigs; this SNP has since been classified as a quantitative trait nucleotide [QTN] (Van Laere et al. 2003). It is considered likely that the ' $A$ ' allele prevents binding of a transcriptional repressor protein to the IGF2 gene; hence individuals inheriting a sire-derived ' $A$ ' allele at this locus display increased muscle growth and a corresponding reduction in body fat due to increased expression of padumnal IGF2 mRNA (Van Laere et al. 2003; Stinckens et al. 2007). Other studies have demonstrated similar phenotypic effects attributable to this QTN in other pig populations (Jungerius et al. 2004; Estellé et al. 2005; Stinckens et al. 2007).

The observed phenotypic associations between DNA sequence polymorphisms within the IGF2 locus and animal carcass and growth traits, as reported in the current study and elsewhere, are not surprising as it encodes an important fetal mitogen (DeChiara et al. 1991; Giannoukakis et al. 1993). While functional genetic studies have identified a causal mutation for muscle mass and fat deposition in pigs (Van Laere et al. 2003), no such causal mutations have yet been identified within the orthologous IGF2 locus in cattle. It has been proposed that the observed associations between the IGF2C.-292C>T SNP and muscle mass and fat content could be due to the location of the SNP in a regulatory region of the IGF2 gene, which may alter the efficiency of IGF2 mRNA translation and stability (Goodall \& Schmutz, 2007). Initially, this SNP was reported within the untranslated exon 2 of the bovine IGF2 gene (Goodall \& Schmutz, 2003; Goodall \& Schmutz, 2007); however, inspection of the currently annotated bovine IGF2 gene in the Ensembl database (Ensembl gene ID ENSBTAG00000013066; Ensembl release 58 of the $B$. taurus genome) locates the IGF2C.-292C>T SNP 54 bp before the start of the 5' UTR of the IGF2 gene (Ensembl transcript ID ENSBTAT00000017372). As per Build 4.0 of the B. taurus genome (Ensembl release 58), the IGF2C.-292C $>T$ SNP is located at nucleotide position 51257871 on BTA29 and has not yet been deposited within the bovine dbSNP database (http://www.ncbi.nih.gov/projects/SNP). Despite the relocation of this SNP from an untranslated exon sequence to $54 \mathrm{bp}$ upstream of the gene, it is possible that this polymorphism influences, or is linked to a polymorphism that regulates IGF2 expression, thereby accounting for the observed associations with bovine carcass traits.

Notably, none of the SNPs analysed in this study were located in amino-acid coding exons of the IGF2 gene or within untranslated IGF2 exonic sequences. Indeed, only one SNP [( $r$ 42194733; located in IGF2 intron 2 based on the annotation of the bovine IGF2 gene (Ensembl ID ENSBTAG00000013066)] was located within the IGF2 gene region; all other SNPs were located upstream or downstream of the gene. As with the intronic IGF2 QTN described in pigs by Van Laere et al. (2003), it is possible that the intronic rs42194733 SNP has a similar function 
in regulating IGF2 expression, possibly through interference with repressor proteins; however, functional genetic studies are required to confirm this. It is more plausible, however, that this SNP is itself associated with a regulatory SNP (or set of SNPs) located proximal to, or within the IGF2 locus.

\section{Associations with milk performance traits}

In the current study, significant associations between all four assayed SNPs and milk performance traits were detected (Table 3). The A to $G$ allele substitution at the IGF2.g-3815A>G SNP was positively associated with both milk yield and milk protein yield, and was negatively associated with milk protein percentage. A tendency to be associated $(P \leqslant 0 \cdot 10)$ with milk fat percentage was also evident at this locus; however, this SNP did not display any association with milk fat yield. Similar phenotypic associations with milk yield were also observed at the rs42196909 locus, where an A-to-G substitution was associated $(P \leqslant 0 \cdot 05)$ with improved milk yield and milk protein yield and tended to be associated $(P \leqslant 0 \cdot 10)$ with reduced milk protein percentage. Again, the similar phenotypic associations support the existence of an upstream IGF2 haplotype incorporating both the IGF2.g-3815A>G and rs42196909 SNP loci. Finally, the A-to-G allele substitution at the rs42196901 SNP, located downstream of the IGF2 gene, was the only SNP associated $(P \leqslant 0 \cdot 05)$ with increases in milk fat yield and milk fat percentage. A tendency to be associated $(P \leqslant 0 \cdot 10)$ with increased milk protein percentage was also observed for this marker; however, this SNP was not associated with milk yield or milk protein yield.

Recently there have been a number of publications indicating that the bovine IGF2 locus may also harbour a QTL for milk production traits. Ashwell et al. (2004) detected a QTL associated with milk production traits on BTA29; however, this QTL was localized to the centromeric region of BTA29, whereas IGF2 maps to the telomeric region of this chromosome. More recently, Flisikowski et al. (2007) observed associations between an insertion/deletion polymorphism in the non-translated exon 6 of the bovine IGF2 gene and estimated breeding values (EBV) for milk yield, milk fat yield and milk protein yield in Holstein-Friesian bulls. Furthermore, associations with milk traits including milk yield and milk constituents have been reported at haplotypes constructed from the C-to-T SNP located at position 51257871 and a G-to-T non-amino acid changing substitution in the translated exon 10 of the IGF2 gene (nucleotide position 51273733 on BTA29) in Polish Holstein-Friesian cows (Bagnicka et al. 2010).

The open reading frame gene model location of the SNPs analysed here (two upstream, one intronic and one downstream) does not immediately suggest that these polymorphisms are functional. Instead, our results suggest that these IGF2 SNPs are associated with a causal regulatory mutation (or set of mutations) located proximal to, or within the IGF2 locus that has not yet been identified. It is noteworthy that previous studies have implicated IGF2 as playing a role in mammary gland development. For example, local infusion of the IGF-II protein has been shown to increase milk production in goats (Prosser et al. 1994) while studies in mice have shown that locally secreted IGF-II mediates the effect of prolactin on mammary gland development (Hovey et al. 2003). Another possible candidate gene harbouring a QTL for milk production on BTA29 is the insulin (INS) gene, which encodes the insulin hormone peptide and is located $\sim 9.3 \mathrm{~kb}$ upstream of the bovine IGF2 gene. It is possible that the observed associations reported here between SNPs within the IGF2 locus may in fact be due to strong LD between the SNPs described here and unidentified functional polymorphisms associated with the INS gene. This hypothesis is supported by the role of the insulin protein in mediating mammalian gland development and lactation in dairy cattle (Akers, 2006).

\section{Conclusion}

The identification of DNA sequence variations associated with body composition and milk performance traits make the imprinted bovine IGF2 gene an attractive target for future dairy cattle breeding programmes. The detection of association between a single genotyped SNP in the current study and traits related to animal growth also support this locus as harbouring a potentially important QTN(s) for beef breeding as observed in other cattle genetic studies and studies in other domestic species, most notably pigs. Furthermore, the results presented here add to an accumulating body of research showing that imprinted genes contribute to many complex performance traits in cattle and other livestock species. These findings, together with the documented biological roles of mammalian imprinted genes in mediating growth and development suggest that they represent an important reservoir of molecular markers for future genetic improvement of dairy and beef cattle populations.

This work was supported by a Research Stimulus Grant from the Irish Department of Agriculture, Fisheries and Food (project number: RSF-06-0406, RSF-06-0353; RSF-06-0409) and Investigator Programme Grants from Science Foundation Ireland (SFI/01/F.1/B028 and SFI/08/IN.I/B2038). MPM was funded by Science Foundation Ireland research grant number 07/SRC/ B1156.

\section{References}

Akers RM 2006 Major advances associated with hormone and growth factor regulation of mammary growth and lactation in dairy cows. Journal of Dairy Science 89 1222-1234

Ashwell MS, Heyen DW, Sonstegard TS, Van Tassell CP, Da Y, VanRaden PM, Ron M, Weller JI \& Lewin HA 2004 Detection of 
quantitative trait loci affecting milk production, health, and reproductive traits in Holstein cattle. Journal of Dairy Science 87 468-475

Bagnicka E, Siadkowska E, Strzalkowska N, Zelazowska B, Flisikowski K, Krzyzewski J \& Zwierzchowski L 2010 Association of polymorphisms in exons 2 and 10 of the insulin-like growth factor 2 (IGF2) gene with milk production traits in Polish Holstein-Friesian cattle. Journal of Dairy Research 77 37-42

Barrett JC, Fry B, Maller J \& Daly MJ 2005 Haploview: analysis and visualization of LD and haplotype maps. Bioinformatics 21 263-265

Bartolomei MS 2009 Genomic imprinting: employing and avoiding epigenetic processes. Genesand Development 23 2124-2133

Bartolomei MS, Zemel S \& Tilghman SM 1991 Parental imprinting of the mouse H19 gene. Nature 351 153-155

Berry DP, Kearney F \& Harris B 2009 Genomic selection in Ireland. In: Proceedings of the Interbull Workshop, Uppsala, Sweden

Berry DP, Shalloo L, Cromie AR, Veerkamp RF, Dillion P, Amer PR, Kearney JF, Evans RD \& Wickham B 2007 The economic breeding index: a generation on. Technical report to the Irish Cattle Breeding Federation

Butterfield RM 1988 New Concepts of Sheep Growth. Sydney, Australia: Department of Veterinary, Univerisity of Sydney

Casas E, Shackelford SD, Keele JW, Koohmaraie M, Smith TP \& Stone RT 2003 Detection of quantitative trait loci for growth and carcass composition in cattle. Journal of Animal Science 81 2976-2983

Chao W \& D'Amore PA 2008 IGF2: epigenetic regulation and role in development and disease. Cytokine Growth Factor Reviews 19 $111-120$

Curchoe C, Zhang S, Bin Y, Zhang X, Yang L, Feng D, O'Neill M \& Tian XC 2005 Promoter-specific expression of the imprinted IGF2 gene in cattle (Bos taurus). Biology of Reproduction 73 1275-1281

DeChiara TM, Robertson EJ \& Efstratiadis A 1991 Parental imprinting of the mouse insulin-like growth factor II gene. Cell 64 849-859

Dindot SV, Farin PW, Farin CE, Romano J, Walker S, Long C \& Piedrahita IA 2004a Epigenetic and genomic imprinting analysis in nuclear transfer derived Bos gaurus/Bos taurus hybrid fetuses. Biology of Reproduction 71 470-478

Dindot SV, Kent KC, Evers B, Loskutoff N, Womack J \& Piedrahita JA 2004 b Conservation of genomic imprinting at the XIST, IGF2, and GTL2 loci in the bovine. Mammalian Genome 15 966-974

Estellé J, Mercadé A, Noguera JL, Perez-Enciso M, Ovilo C, Sanchez A \& Folch JM 2005 Effect of the porcine IGF2-intron3-G3072A substitution in an outbred Large White population and in an Iberian $\times$ Landrace cross. Journal of Animal Science 83 2723-2728

Feil R 2009 Epigenetic asymmetry in the zygote and mammalian development. International Journal of Developmental Biology 53 191-201

Feil R, Khosla S, Cappai P \& Loi P 1998 Genomic imprinting in ruminants : allele-specific gene expression in parthenogenetic sheep. Mammalian Genome 9 831-834

Flisikowski K, Adamowicz T, Strabel T, Jankowski T, Switonski M \& Zwierzchowski L 2007 An InDel polymorphism in exon 6 of IGF2 associated with the breeding value of Polish Holstein-Friesian bulls. Biochemical Genetics 45 139-143

Giannoukakis N, Deal C, Paquette J, Goodyer CG \& Polychronakos C 1993 Parental genomic imprinting of the human IGF2 gene. Nature Genetics 4 98-101

Gilmour AR, Cullis BR, Welham SJ \& Thompson R 2009 ASREML Reference Manual. Orange Agricultural Institute, Orange: New South Wales Agriculture.

Goodall JJ \& Schmutz SM 2003 Linkage mapping of IGF2 on cattle chromosome 29. Animal Genetics 34313

Goodall JJ \& Schmutz SM 2007 IGF2 gene characterization and association with rib eye area in beef cattle. Animal Genetics 38 154-161

Heuven HC, van Wijk RH, Dibbits B, van Kampen TA, Knol EF \& Bovenhuis H 2009 Mapping carcass and meat quality QTL on Sus scrofa chromosome 2 in commercial finishing pigs. Genetics Selection Evolution 41

Hill WG \& Robertson A 1968 Linkage disequilibrium in finite populations. Theoretical Applied Genetics 38 226-231
Hou G, Wang D, Guan S, Zeng H, Huang X \& Ma Y 2010 Associated analysis of single nucleotide polymorphisms of IGF2 gene's exon 8 with growth traits in Wuzhishan pig. Molecular Biology Reports 37 497-500

Hovey RC, Harris J, Hadsell DL, Lee AV, Ormandy CJ \& Vonderhaar BK 2003 Local insulin-like growth factor-II mediates prolactin-induced mammary gland development. Molecular Endocrinology 17 460-471

Jeon JT, Carlborg O, Tornsten A, Giuffra E, Amarger V, Chardon P, Andersson-Eklund L, Andersson K, Hansson I, Lundstrom K \& Andersson L 1999 A paternally expressed QTL affecting skeletal and cardiac muscle mass in pigs maps to the IGF2 locus. Nature Genetics 21 157-158

Jungerius BJ, van Laere AS, Te Pas MF, van Oost BA, Andersson L \& Groenen MA 2004 The IGF2-intron3-G3072A substitution explains a major imprinted QTL effect on backfat thickness in a Meishan $\times$ European white pig intercross. Genetics Research 84 95-101

Lewontin RC 1964 The interaction of selection and linkage. I. General considerations; heterotic models. Genetics 49 49-67

Li C, Bin Y, Curchoe C, Yang L, Feng D, Jiang Q, O'Neill M, Tian XC \& Zhang S 2008 Genetic imprinting of $\mathrm{H} 19$ and IGF2 in domestic pigs (Sus scrofa). Animal Biotechnology 19 22-27

Magee DA, Berkowicz EW, Sikora KM, Berry DP, Park SDE, Kelly AK, Sweeney T, Kenny DA, Evans RD, Wickham BW, Spillane C \& MacHugh DE 2010 A catalogue of validated single nucleotide polymorphisms in bovine orthologs of mammalian imprinted genes and associations with beef production traits. Animal [Epub ahead of print]

McGrath J \& Solter D 1984 Completion of mouse embryogenesis requires both the maternal and paternal genomes. Cell 37 179-183

McLaren RJ \& Montgomery GW 1999 Genomic imprinting of the insulinlike growth factor 2 gene in sheep. Mammalian Genome 10 588-591

Nezer C, Moreau L, Brouwers B, Coppieters W, Detilleux J, Hanset R, Karim L, Kvasz A, Leroy P \& Georges M 1999 An imprinted QTL with major effect on muscle mass and fat deposition maps to the IGF2 locus in pigs. Nature Genetics 21 155-156

Nezer C, Moreau L, Wagenaar D \& Georges M 2002 Results of a whole genome scan targeting QTL for growth and carcass traits in a Pietrain $\times$ Large White intercross. Genetics Selection Evolution 34 371-387

O'Dell SD \& Day IN 1998 Insulin-like growth factor II (IGF-II). International Journal of Biochemistry and Cell Biology 30 767-771

Oczkowicz M, Tyra M, Walinowicz K, Rozycki M \& Rejduch B 2009 Known mutation (A3072G) in intron 3 of the IGF2 gene is associated with growth and carcass composition in Polish pig breeds. Journal of Applied Genetics 50 257-259

Prosser CG, Davis SR, Farr VC, Moore LG \& Gluckman PD 1994 Effects of close-arterial (external pudic) infusion of insulin-like growth factor-II on milk yield and mammary blood flow in lactating goats. Journal of Endocrinology 142 93-99

Rachmilewitz J, Goshen R, Ariel I, Schneider T, de Groot N \& Hochberg A 1992 Parental imprinting of the human H19 gene. FEBS Letters 309 25-28

Reik W, Constancia M, Dean W, Davies K, Bowden L, Murrell A, Feil R, Walter J \& Kelsey G 2000 lgf2 imprinting in development and disease. International Journal of Developmental Biology 44 145-50

Rodriguez S, Gaunt TR \& Day IN 2007 Molecular genetics of human growth hormone, insulin-like growth factors and their pathways in common disease. Human Genetics 122 1-21

Schmutz SM \& Goodall JJ 2005 Polymorphism of the IGF2 gene and improving production characteristics of cattle. International Patent Number WO 2005/007881. European Patent Office

Sherman EL, Nkrumah JD, Murdoch BM, Li C, Wang Z, Fu A \& Moore SS 2008 Polymorphisms and haplotypes in the bovine neuropeptide $\mathrm{Y}$, growth hormone receptor, ghrelin, insulin-like growth factor 2, and uncoupling proteins 2 and 3 genes and their associations with measures of growth, performance, feed efficiency, and carcass merit in beef cattle. Journal of Animal Science 86 1-16

Stinckens A, Mathur P, Janssens S, Bruggeman V, Onagbesan OM, Schroyen M, Spincemaille G, Decuypere E, Georges M \& Buys N 
2010 Indirect effect of IGF2 intron3 g.3072G > A mutation on prolificacy in sows. Animal Genetics [Epub ahead of print]

Stinckens A, Van den Maagdenberg K, Luyten T, Georges M, De Smet S \& Buys N 2007 The RYR1 g.1843C>T mutation is associated with the effect of the IGF2 intron3-g.3072G $>$ A mutation on muscle hypertrophy. Animal Genetics 38 67-71

Surani MA, Barton SC \& Norris ML 1984 Development of reconstituted mouse eggs suggests imprinting of the genome during gametogenesis. Nature 308 548-550

Tamura K, Dudley J, Nei M \& Kumar S 2007 MEGA4: Molecular Evolutionary Genetics Analysis (MEGA) software version 4.0. Molecular Biology of Evolution 24 1596-1599

Van Laere AS, Nguyen M, Braunschweig M, Nezer C, Collette C, Moreau L, Archibald AL, Haley CS, Buys N, Tally M, Andersson G, Georges M
\& Andersson L 2003 A regulatory mutation in IGF2 causes a major QTL effect on muscle growth in the pig. Nature 425 832-836

Vykoukalova Z, Knoll A, Dvorak J \& Cepica S 2006 New SNPs in the IGF2 gene and association between this gene and backfat thickness and lean meat content in Large White pigs. Journal of Animal Breeding and Genetics 123 204-207

Waters SM, McCabe MS, Howard DJ, Giblin L, Magee DA, MacHugh DE \& Berry DP 2010 Associations between newly discovered polymorphisms in the Bos taurus growth hormone receptor gene and performance traits in Holstein-Friesian dairy cattle. Animal Genetics [Epub ahead of print]

Zhang S, Kubota C, Yang L, Zhang Y, Page R, O'Neill M, Yang X \& Tian XC 2004 Genomic imprinting of H19 in naturally reproduced and cloned cattle. Biology of Reproduction 71 1540-1544 